\title{
LEGALISM RAMPANT: THE HERITAGE OF IMPOSED LAW AND THE CONSTITUTION OF PAPUA NEW GUINEA $^{1}$
}

\author{
BY JOHN GOLDRING
}

In 1975 Papua New Guinea became independent. Geographically and culturally, its traditional societies were about as far removed from the societies of Western Europe as was possible.

The preamble to the Constitution of the Independant State of Papua New Guinea sets out a number of National Goals, the fifth of which reads, in part:

"We declare our fifth goal to be to achieve development primarily through the use of Papua New Guinean forms of social, political and economic organization.

WE ACCORDINGLY CALL FOR -

(1) a fundamental re-orientation of our attitudes and the institutions of government, commerce, education and religion towards Papua New Guinean forms of participation, consultation, and consensus, and a continuous renewal of the responsiveness of these institutions to the needs and attitudes of the People..."

In fact, the Constitution, while embodying many of the aspirations of liberal-minded people in Papua New Guinea and elsewhere, establishes institutions which are firmly within the intellectual and political traditions of the pluralist demcracies of Western Europe and North America. It is a constitution which is in the highest traditions of English common law legalism, and despite its lip-service to Papua New Guinea forms, if it is the expression of the will of the People, that will is not founded in the traditional cultures of Papua New Guinea, but is a product of western influences. The Constitution itself is a declaration of faith in legalism; its specific provisions are totally dependent on the processes developed by the courts of "common law" countries. The fact that the framers of the Constitution of Papua New Guinea expressly. chose to vest its enforcement and interpretation in judicial courts, flows from the place which the colonial structure had given to the legal process. The preference for a judicial system, not too dissimilar to that which had existed under colonial rule, shows an acceptance not only of the western concept of the impartiality of the judge, which appears alien to traditional Papua New Guinean cultures, but also an acceptance of the idea of the rule of law, in the sense that the State, and its divisions, are entities whose nature, structure and function can be expressed in the form of a certain and inflexible law. This concept of law can only have come from the knowledge and experience of western law, for though there were undoubtedly "laws", in some sense, in traditional Papua New Guinea societies $^{2}$, neither the State, nor law, in the sense that a written constitution is a law, were within the range of concepts of the traditional Papua New Guinean ${ }^{3}$. Thus the very existence of a State of Papua New Guinea with a written Constitution is part of the heritage of imposed law.

\footnotetext{
1 This article deals with the impact of colonial law on the nature and form of the Constitution of Papua New Guinea. The detailed provisions of the Constitution are considered in the author's The Constitution of Papua New Guinea (Sydney 1978).

2 E.g. the various Papua New Guinean societies discussed in A. L. Epstein, ed., Contention and Dispute (Canberra 1974).

3 P. Lawrence, "The State versus Stateless Societies in Papua New Guinea" in B. J. Brown, ed., Fashion of Law in New Guinea, (Sydney 1969).
} 


\section{Historical \& political background ${ }^{4}$}

Papua New Guinea is an independent State, lying immediately north of Australia and adjacent to Irian Jaya, the most southeastern province of Indonesia. Its population, of about 21/2 million, is divided into over 700 language groups, and there are some social differences between each of these groups; some of the differences are significant. Until 1884 the people of the islands which make up Papua New Guinea had little contact with any people from the outside world or with other societies. In that year, the German Empire annexed the Northern half of the island of New Guinea, and the islands of New Britain, New Ireland, New Hanover, Manus and Bougainville, lying to the North and East. In the same year, British naval forces landed in the southern part of the main island, and proclaimed a British Protectorate. The Protectorate was annexed in 1888 . While the German colony was established and maintained for economic reasons, the British Protectorate was a reaction to the German annexation of territory close to the British colonies in Australia, prompted by the anxiety of the British subjects in Australia. After Australia became an independent Dominion, the administration of British New Guinea, which then became known as Papua, was transferred to the government of the Australian Commonwealth. On the outbreak of World War 1, Australian forces occupied the German Territories in the South West Pacific, including New Guinea. The Treaty of Versailles established a League of Nations mandate over New Guinea, to be administered by Australia. Australia, was thus responsible for the administration of both parts of the island until Independence. From 1914 until after the Second World War, however, the two territories were administered separately by Australia, and there was a general similarity in the basic policy, which was to maintain a semblance of law and order at the lowest possible cost. Despite some earnings from mining and agricultural production, the New Guinea territories were not maintained primarily for economic purposes, but rather as a defence measure.

European influence was at first confined to the coastal areas and islands, where, first planters and missionaries, and later government officials established bases. Beyond the shore lay swamps, and incredibly rugged mountains. Little was known of these areas, and not until the 1920 s and 1930s was any serious attempt made to penetrate the interior. When such attempts were made, there were several reasons; survey and census, prospecting, health control, and a desire to prevent fighting between the people and attacks from the interior on Europeans and Papua New Guinean communities which had been contacted. Patrols were generally carried out by a single European officer known as a Kiap, with a handful of native police. After initial contact, further contact usually involved the construction of roads, tracks and airfields. The establishment of a patrol post was usually followed by a first-aid post. Education, by and large, was left to the missions. As new areas were contacted, people from those areas were recruited, generally for two-year periods, to work on the coastal plantations as indentured labourers. Returning labourers were of ten the sole source of information of the world beyond the confines of the village. In the early days of the Australian administration, the people were regarded as incapable of running their own affairs ${ }^{5}$. Local government was not established until the late 1950s, and the first representatives of the Papua New Guinean people in the local legislature (an appointed body with purely advisory functions) were ap-

\footnotetext{
4 Perhaps the best short history of Papua New Guinea is H. Nelson, Papua New Guinea: Black Unity or Black Chaos (Harmondsworth, 1972); reference may also be made to C. D. Rowley, The New Guinea Villager (Melbourne 1965); L. P. Mair, Australia in New Guinea (2nd ed., Melbourne 1970); E. P. Wolfers, Race Relations and Colonial Rule in Papua New Guinea (Sydney 1975) and D. Woolford, Papua New Guinea: Initiation and Independence (Brisbane 1977).

5 See e. g. F. West, Hubert Murray (Melbournc 1968) forthe views of the Administration of Papua from 1909 to 1942 ; and e. g. J. H. P. Murray, Native Administration in Papua (Port Moresby 1924) and similar works.
} 
pointed about the same time. Previously all members of the "Legislative Council" had been white. During the 1960s and 1970s, under pressure from world opinion, and particularly from the World Bank and the bloc of developing countries in the United Nations, Australia began slowly to accept the need for a move towards some form of self-government. A greater proportion of elected members was provided for in the legislature; the legislature itself was given more powers, and members of the legislature were given "understudy" roles to the "official" members who held office by virtue of their position of heads of departments of the administration. By $1968^{6}$, only a few official appointed members remained in the legislature; the members elected "ministers", who, though having no controlling function in the formation of policy, did participate in the functioning of their departments and represented the departments and the Administration in the House of Assembly, as it was then known. At the House of Assembly General Election held in April 1972, a majority of seats was obtained by supporters of a group which became known as the "National Coalition", with a policy of immediate self-government and independence from Australia within a short time. A recent change of Ministers in Australia had led to the appointment of a Minister sympathetic to the nationalist movement in Papua New Guinea, and later in the year, the election of a Labor Government in Australia brought to office an Australian Ministry committed to independence within the shortest possible time. At no time was there any armed struggle, or even serious repression of nationalist politicians.

The legal system of the Territory of Papua New Guinea was very definitely within the common law tradition. The common law of England, as administered in the Australian State of Queensland, had been "received" in Papua New Guinea, to the extent that it was applicable and appropriate to the circumstances, by "reception statutes" in both Papua and New Guinea ${ }^{7}$. The Criminal Law was the Queensland Criminal Code, as adopted, together with Police Offences legislation copied in the main from that of the Australian States, with some minor variations ${ }^{8}$. There was, in addition, a considerable amount of local legislation, made under Ordinances dealing with "Native Affairs", and these regulations were the primary means of legal administrative control. If a Papua New Guinean came into contact with the law, it was generally with the criminal law or the Native Regulations ${ }^{9}$. Much legislation dealt with title to land. Especially in New Guinea, where the Germans had acquired considerable tracts of land by force or unequal bargains, from groups of people in whose tradition land was incapable of permanent alienation, many of the people had resorted to legal procedures to assert their claims to land held by the administration or by white settlers ${ }^{10}$.

The laws were administered by a judicial system based on that in England and Australia. There was no use of traditional dispute settlement procedures, which were not recognised officially in any way, though the existence of such procedures had been recognised by the early $1930 \mathrm{~s}^{11}$. Later studies concentrated specifically on the operation of traditional and popular dispute settlement processes and showed conclusively that perceptions of justice and

\footnotetext{
6 P. J. Bayne and H. K. Colebatch, Constitutional Development in Papua New Guinea, 1968-1973, (New Guinea Research Bulletin No. 51, Canberra 1973).

7 R. S. O'Regan, The Common La w in Papua and New Guinea (Sydney 1971); "Codes and Common Law in Papua and New Guinea" (1971), Melanesian Law Journal 5; "The Common Law Overseas-A Problem of Applying the Test of Applicability" (1971) 20 International and Comparative Law Quarterly 342; "The Common Law and English Statutes in Papua New Guinea" (1972) 45 Australian Law Journal 297. For an earlier view, J. R. Mattes "Sources of Law in Papua and New Guinea" (1963) 37 Australian Law Journal 148.

8 S. H. Johnson, "Criminal Law and Punishment" in Brown, op cit., n. 3.

9 Wolfers, op. cit., n. 4.

10 F. B. Phillips, "Native Land; its Acquisition under German and Australian Law" in Brown, op. cit., n. 3; P. G. Sack, Land Between Two Laws (Canberra 1973).

11 E.g. J. A. Todd, "Native Offences and European Law in South-West New Britain" (1935) 5 Oceania 437.
} 
the judicial process were still couched in terms of popular tradition ${ }^{12}$. The Law was seen as something imposed by white man; this was also true of the political system. There was no use of "indirect rule" as a means of control, as had been the case in India and Africa. From the beginning of British-Australian colonisation of Papua New Guinea, the imposition of Western values in the guise of "maintenance of law and order" was an important aspect of policy; British justice was seen as something of value to be passed on to the unenlightened natives ${ }^{\mathbf{1 3}}$. This view persisted up to Independence among some lawyers. Thus expansion of formal courts was seen as a priority for development ${ }^{14}$. The courts were not seen as varying greatly from those in other common law countries; the legislation and the procedures which they applied would have been familiar to any English practitioner. The legal profession comprised Judges, of whom, at Independence, all but one were Australians ${ }^{\mathbf{1 5}}$; a relatively small private legal profession, catering primarily for the needs of white residents and businesses, and a relatively large body of lawyers employed by the Government, as prosecutors, as salaried legal aid officers in the Public Solicitor's office, and as magistrates ${ }^{\mathbf{1 6}}$. Some Papua New Guineans had, since 1963, been trained as magistrates ${ }^{17}$, and from 1966, Papua New Guineans had been enrolled as law students in the Faculty of Law at the University of Papua New Guinea. At first Law courses were modelled on those in Australian Universities ${ }^{18}$, but from the outset, from time to time, changes to the nature of the structure of the courses were made so that the legal education was more closely suited to the needs of the country ${ }^{19}$. The Papua New Guinean lawyer was and is recognisably a part of the common law tradition.

In both parts of the territory there were superior courts constituted by qualified lawyers. These courts dealt with serious offences, and with civil claims, the parties to which were almost always Europeans. Lower courts were for the most part constituted by Kiaps. In Papua, the Kiaps in charge of administrative districts were officially called "Resident Magistrates" though few of them had more than a rudimentary training in law. Kiaps performed the function of detective, prosecutor and gaoler as well as of judge. There were cases of abuse of judicial power ${ }^{20}$. After 1963 the proportion both of full-time and Papua New Guinean magistrates increased.

\section{The making of the Constitution}

After taking Office, the National Coalition Government immediately appointed a Constitutional Planning Committee (henceforth CPC) to plan the structure and content of the Constitution of the country under self-government and independence. This Committee was composed of fifteen members of the House of Assembly, representing all political parties and all the major regions of the Country. The Chief (now Prime) Minister, M. T. Somare, was ex officio Chairman of the Committee. The former Minister of Justice, John Kaputin,

12 D. M. Fenbury "Kot Bilong Mipela" (1965) New Guinea Australia and the Pacific 65; T. E. Barnett, "The Local Court Magistrate and the Settlement of Disputes' in Brown, op cit., n. 3; A. M. Strathern, Official and Unofficial Courts (New Guinea Research Bulletin No. 47, Canberra 1972); A. L. Epstein, ed, op. cit., n. 2., passim.

13 R. T. Gore, The Punishment for Crime Among the Natives of Papua New Guinea (Appendix to Territory of Papua, Annual Report 1929-30) (Canberra, 1930).

14 E.g. P. M. C. Hasluck, A Time for Building (Melbourne, 1976) Ch. 16.

15 S. D. Ross, "A Review of the Judiciary in Papua New Guinea" (1977) 5 Melanesian Law Journal 5.

16 S. D. Ross, "The Legal Profession in Papua New Guinea" (1978) 5 Melanesian Law Journal 226.

17 Barnett, loc. cit. n. 12.

18 P. G. Nash, "Problems of Legal Education in Papua and New Guinea" in Brown, op. cit. n. 3.

19 R. W. James, "Developments in Legal Education in the Faculty of Law, University of Papua New Guinea" (1975) 3 Melanesian Law Journal 185.

20 J. R. Mattes, "The Courts System" in Brown op. cit. n. 3. 
was also a member. Both Somare and Kaputin were strong critics of the legal system and advocates of nationalism in all things, not least the $\mathrm{law}^{21}$. The Deputy Chairman of the Committee was a Doctor of Canon Law from a Roman religious university (and also an intelligent and dedicated nationalist). Other members of the Committee had virtually no formal education. The Committee commenced meeting in 1972. It appointed consultants; most of the permanent consultants were political scientists, though the staff also included a Papua New Guinean lawyer educated in Australia, and an Australian with a background in Comparative Constitutional Law. Occasional consultants included a number of lawyers, many of whom had a significant connection with Tanzania. This connection may be reflected in some of the institutions which are established by the Constitution, though the text of the Constitution does not really resemble that of the text of the Constitution of Tanzania, or that of any other single country.

The most remarkable thing about the work of the CPC was the degree to which it sought popular opinion upon the matters to be included in the Constitution. The workings of the CPC have been described in some detail ${ }^{22}$ and were quite formal. A subject would be introduced by the Deputy Chairman or another member of the Committee. After some discussion and agreement on principles, the consultants would prepare a report in the form of a working paper, including comparative material. This would be the basis for further discussion. Following this, the Committee would prepare a press statement on the subject. This would be distributed by government political education officers throughout the country, to discussion groups organised at village and local government council level. There were several hundreds of these groups. The groups would then discuss the matters raised by the CPC in the Press statement, and the results of these discussions would be sent back to the CPC. The CPC also arranged to tour the country, visiting every administrative sub-district at least once, and meeting, in its own estimation, over 60,000 people at public meetings. The Press statements were also widely publicised in English and in the principal linguae francae in the press and on the radio. This publicity always included an invitation to members of the public to make known their own views on the subject to the CPC. It was not, of course, practical to "consult" on technical detail, and consultation was, for the most part, limited to matters of principle. On some issues, such as Citizenship, Human Rights, and participation in the process of government, the CPC appears to have been influenced considerably by public reaction to the proposals it circulated. The final text of the CPC Report ${ }^{23}$ consisted of a set of drafting instructions with explanatory notes. The CPC wished that in substance and in form the Constitution should be and be seen as an expression of the popular will. Though the Committee was appointed by the Administrator, as the Representative of the Australian Government, the Report was consciously submitted to the Chief Minister as the elected representative of the majority of the people.

\section{Autochthony}

Many constitutions of former British colonies which have gained independence are expressed as being the opinion of the people, but in the strictlegal sense, the authority of those constitutions is based in the previous law. In many cases the constitution itself is embodied in

\footnotetext{
21 M. T. Somare, "Law and the Needs of Papua New Guinea's People" in P. J. Bayne and J. Zorn, eds., Lo Bilong Ol Manmeri(Port Moresby 1973), J. R. Kaputin, "The Law - A Colonial Fraud" (1973) New Guinea, Australia and the Pacific (2) 4.

22 B. M. Narokobi, "We the People, We the Constitution" in Bayne and Zorn, op. cit. n. 21.

23 Papua New Guinea, Final Report of the Constitutional Planning Committee (Port Moresby, 1974) (henceforth "C. P. C. Report").
} 
Imperial legislation. This was the case of the Australian Constitution, that of Sri Lanka, and also of many African constitutions. In Papua New Guinea, this was not the legal form adopted. Immediately prior to Independence Day, the Papua New Guinea Independence Act 1975 (Australia) came into effect. This Act repealed the Papua New Guinea Act 1949, an Australian Act which established the organs of government and the authority of Australia over the Territory of Papua New Guinea. The 1975 Act also repealed all other Australian legislation applying to Papua New Guinea.

For an instant, no formal laws applied in Papua New Guinea. At the beginning of Independence Day, September 15th, 1974, the Constitution of the Independent State of Papua New Guinea came into force. It was not part of Australian law. Its authority was expressed to be founded in the will of the people of the country, and rested on assertions contained in its own text, and, unlike other constitutions, did not rest ultimately on the legal principles of the English common law, in which may be found the principle of sovereignty of Parliament, the Grundnorm or basic legislative authority not only for Acts of Parliament of the United Kingdom, but also for the Constitutions of Australia, Sri Lanka, Canada and other apparently autonomous States ${ }^{24}$. In form, as well as in formation, the Constitution was the product of the will of the people.

It was not, of course, the direct result of popular participation. The CPCReport had drawn a response from the Government and during the CPC's proceedings there were at times bitter disputes between CPC and Government. The final Government response ${ }^{25}$, however, disagreed with the CPC on a relatively few issues possibly because at this stage most members of the Assembly supported the CPC rather than the Government: these issues included whether or not there should be a Head of State, Citizenship, and especially the conditions which non-indigenous Papua New Guineans must fulfil before becoming citizens, and the establishment of provincial government. The CPC had seen no reason for a Head of State; in Papua New Guinea there was no tradition of heredity or elective leadership; this function was performed on an ad hoc basis, different members of the community providing leadership for different purposes. The functions traditionally performed by a Head of State, could, in the view of the CPC, be performed by either the Prime Minister as the head of the elected Government, by the Speaker as the head of the Parliament, or by the Chief Justice as head of the Judiciary ${ }^{\mathbf{2 6}}$. The CPC also proposed ${ }^{\mathbf{2 7}}$, that an extensive system of provincial government should be established in order to reduce the size of the disproportionately large bureaucracy which had been established by the Australians, and as a means of allowing greater popular participation in government. Though the Government accepted the idea of provincial government in principle, for a veriety of reasons the Independence Constitution made no mention of the subject, which was at last introduced by Constitutional Amendment late in $1976^{28}$. The Government did not even disagree, in principle, except on the issue of the Head of State; the citizenship proposals were accepted in theory. However, the conditions for granting of citizenship to persons other than those who had two grandparents born in Papua New Guinea were slightly less restrictive than the CPC had proposed ${ }^{29}$. The CPC it-

24 C. f. R. T. E. Latham, "The Law of the Commonwealth" in W. K. Hancock, ed., Survey of British Commonwealth Affairs, Vol. (London 1937).

25 Papua New Guinea, Proposals on Constitutional Principles and Explanatory Notes (Port Moresby, 1974).

26 E. P. Wolfers "Discretion, Politics and Governors-General: Some Comparisons Between Papua New Guinea and Australia" (1977) 49 Australian Quarterly (2) 75.

27 C. P. C. Report, Chapter 10.

28 Constitutional Amendment No. 1 of 1976, introducing Part VIA into the Constitution: for a history of this legislation, see D. Conyers, The Provincial Government Debate (I. A. S. E. R. Monograph No. 2 Port Moresby 1976).

29 E. P. Wolfers, "Defining a Nation: The Citizenship Debates in the Papua New Guinea Parliament" inF. S. Stevens and E. P. Wolfers, eds., Recism, The Australian Experience, Vol. 3. Colonialism and After (2nd ed., Sydney, 1977). 
self saw the need for further and more concrete proposals on the question of provincial government. But because the Government, under considerable pressure from the civil servants, stated that there was insufficient time fully to develop these proposals before Independence, the matters are not mentioned, except obliquely, in the text of the Constitution. Some have been enacted subsequently by ordinary legislation. The proposals of both the CPC and the Government were fully debated by a Constituent Assembly, comprising all the elected members of the House of Assembly. This Assembly resolved to adopt the document which became the Constitution. No separate election was held for the Constituent Assembly, but the members had been elected a little over two years previously, and were reasonably representative of the people. It is a peculiarity of Papua New Guinea politics that politicians depend a great deal on personal contact and responsiveness to the attitudes of their constituents, and party affiliation is not as important as it is in some other countries. Most Papua New Guinean politicians consider themselves obliged to make serious efforts to consult their constituents, and find that if they fail to do so they will not be re-elected.

\section{The Constitution as a Political Statement}

All Constitutions are political statements. By definition, it is the Constitution which establishes the power structure, and the nature of that structure depends on the will of those with the power; it determines for the indefinite future the way in which political power will be exercised. The political assumptions which are the foundation of most constitutions are not stated expressly in the text of the Constitutions. Again, Papua New Guinea sets a new trend. The Preamble to the Constitution contains a series of "National Goals and Directive Principles, Basic Rights, and Basic Social Obligations" which are a frank statement of a general political direction which specific national policies should follow. The titles of the National Goals indicate the types of political principles which are involved; Integral Human Development; Equality and Participation; National Sovereignty and Self-Reliance; Conservation and use for the collective benefit of Natural Resources and the Environment; and Papua New Guinean Ways. These goals and principles are not enforceable directly as law; s. 25 of the Constitution provides that while they are "non-justiciable"30, "Nevertheless, it is the duty of all governmental bodies to apply and give effect to them as far as lies within their respective powers." The section makes further provisions for the Goals and Principles to be applied by the Courts in interpreting the law and formulating new principles of law or new applications of established principles of law; by the Law Reform Commission, and by the Ombudsman Commission when supervising the functioning of the administrative machinery. It was the wish of the CPC that the Constitution would also include an "Investment Code" governing the circumstances in which foreign enterprise and capital would be permitted in the country, but the Government's view, which was that such a code, though necessary and desirable for Papua New Guinea, would need to be very detailed and better left to ordinary legislation, prevailed in the Constituent Assembly.

Other provisions of the Constitution, which are enforceable as such, are also political in content. Sections 50-56 provide constitutionally guaranteed rights, including rights to property and of political activity, but only to citizens. These provisions are designed to ensure that whites do not dominate the economy, or political activity. Part III, 2, the "Leadership

30 Schedule 1.7. explains the expression "non-justiciable": "Where a Constitutional Law Declares a question to be non-justiciable, the question may not be heard or determined by any court or tribunal . .." 
Code", and ss. 127-130 impose stringent restrictions upon the sources from which politicians and political parties may receive support; politicians and "leaders", i.e. those holding high political, administrative or judicial office, are forbidden to hold interests in certain business activities, particularly those in which foreigners are involved. The provisions were a reaction to widespread corruption in other developing countries. The Basic Rights guaranteed by Division III. 3 are also political; they signify acceptance of an individualistic or pluralistic parliamentary democracy.

The essential political message that one might draw from the Constitution is that the sort of society which the framers of the Constitution envisaged was a pluralistic social democracy in which the rights of the individual were more highly regarded than rights of property, but in which the individual was part of a community; indeed, this is virtually spelt out in the notion of "development" as the development of the individual as an integral person within a community, which is the first of the National Goals. The Constitution establishes the organs of the State as providing a wide range of services and amenities for the people. Although the Constitution provides for the acceptance and recognition of a wide variety of traditions, not least as the basis for the system of laws, the general structure is that of a liberal democracy in the Western tradition, with economic policies which may be incompatible with uncontrolled western capitalism.

\section{The Power Structure}

The Constitution establishes a unicameral legislature, with a number of single-member constituencies of equal population. There are also to be "provincial" electorates ${ }^{\mathbf{3 1}}$. This Parliament has unfettered legislative power and a power to review all delegated legislation ${ }^{32}$. Any citizen is entitled to vote ${ }^{33}$, and provided that he or she is of a certain age and has the required residential connection with the electorate, and is not subject to the usual type of disqualification, may stand for election ${ }^{34}$. Ministers, though appointed by the Head of State on the advice of the Prime Minister, must be Members of the Parliament and may be removed by a vote of the Parliament. General elections are to be held every five years, unless, at least four years after a General Election, Parliament passes a motion of no confidence in the Prime Minister or the Ministry, in which case a General Election is to be held immediately. In other cases a motion of no confidence in the Prime Minister has to nominate the next Prime Minister, who shall take office if the motion is passed ${ }^{\mathbf{3 5}}$.

The Constitution also provides for the appointment of a Speaker and a parliamentary staff, including a legal adviser to assist with the drafting of legislation ${ }^{36}$. All private members have the right to speak and move motions in the House ${ }^{37}$. The Queen of England is the Head of State, but acts through a Governor-General elected by the Parliament. The Head of State may only act "with and in accordance with" the advice of the National Executive Council, comprising the Ministers. The Head of State and National Executive Council together form the National Executive, in whom the executive power of the people is vested ${ }^{\mathbf{3 8}}$.

\footnotetext{
31 Constitution, s. 101.

32 Ibid., s. 100.

33 Ibid., s. 99 (2).

33 Ibid., ss. 50, 126.

34 Ibid., s. 103.

35 Ibid., ss. $141-148$.

36 Ibid., ss. 107-8, 132.

37 Ibid., s. 111.

38 Ibid., Part V.
} 
The Constitution also establishes a National Court, and other courts, but not including the village courts established by the Village Courts Act 1974 and courts settling disputes over land in accordance with customary rules ${ }^{39}$. The Supreme Court has the power of interpreting the Constitution ${ }^{\mathbf{4}}$. The CPC consciously considered whether a task of such political delicacy as the interpretation of the Constitution should be vested in a body whose members were not elected by, or responsible either directly or indirectly to the people, but decided that the expertise of the judiciary made them solely qualified for the task, even though, in the early years of independence, when matters of Constitutional interpretation could prove vital, the members of the judiciary were unlikely to be citizens of the new State ${ }^{\mathbf{4}}$.

A number of ancillary organs are appointed to ensure that the machinery of government functions in the desired way. Matters of appointment and service of public servants are vested in a Public Services Commission ${ }^{42}$. A Judicial and Legal Services Commission controls the appointment and discipline of judges and magistrates (other than the Chief Justice, for whom special provision is made) ${ }^{43}$. Special provisions are made for civilian control of the disciplined forces (defence force and police) ${ }^{44}$. Of these organs, perhaps the most important is the Ombudsman Commission. This body, which follows fairly closely the Tanzanian model, has not only the functions normally associated with Ombudsmen, i.e. to ensure that administration takes place on a proper basis, fairly and according to law; but it also has the function of ensuring compliance with the "leadership code". In all its functions the Ombudsman Commission has both an investigative and a quasi-curial function, and is required by constitutional provisions to decide questions of law. It may be seen as a response, albeit in a common law country, to demands for a system of administrative tribunals, with power to review administrative decisions both on matters of law and on the merits ${ }^{45}$. The Constitution also establishes the office of Auditor-General and a Parliamentary Public Accounts Committee whose function it is to scrutinize and report upon public expenditure ${ }^{\mathbf{4 6}}$. In addition to more usual constitutional statements, which provide the skeleton of a governmental structure, the Constitution specifies a number of matters of detail which would, in other constitutions, be found in ordinary Acts of the Parliament, and even in subordinate legislation and Standing Orders of the Parliament.

The doctrine of separation of powers is incorporated into the Constitution by s. 99(3) of the Constitution, but this is "in principle" only, which is defined as having the effect that an exercise of a function which prima facie belongs to one arm of the Government cannot be invalidated because it has been done by some other arm. However, the functions of each organ of government is laid down by law - in many cases in the Constitution itself, and s. 155 gives to the National Court a power to review any action by way of the prerogative writs. All bodies which may make decisions affecting the rights of citizens are required to act in accordance with the principles of "natural justice", defined in Division III. 4 of the Constitution as being the principles of natural justice known to the common law. Thus a rather difficult collection of legal concepts, whose nature, function and extent are a matter which, in the last resort, can only be determined by lawyers, is built by the Constitution into the governmen-

\footnotetext{
39 Ibid., Part. VI. 5.

40 Ibid., Part. II. 2. c.

41 C. P. C. Report paras $8.133-8.149$.

42 Constitution, Part VII.2.

43 Ibid. ss. 168-183.

44 Ibid., Parts VII. 4, VII. 5.

45 Ibid., Part VIII. 2.

46 Ibid., Part. VIII. 1.
} 
tal structure ${ }^{47}$. Detailed provisions of the Constitution also govern the formation of political groups and parties, and the campaign expenditure of parliamentary parties ${ }^{48}$. These measures are not designed as a restriction on political activity, but rather as a means of safeguarding the national political process from interference by foreigners, who, in the past, by donations to political parties, have sought to influence the course of political events. Enforcement of these restrictions is in the hands of the Ombudsman Commission and the Courts.

The power structure established by the Constitution of Papua New Guinea is prescribed in detail; but the Constitution is not a mere framework for a political structure. Though there is some flexibility, many matters are rigidified by constitutional provisions, and it is likely that those with an interest in challenging the activities of government will be able to use the processes of law to ensure that the provisions of the laws are scrupulously observed.

\section{The Legal System}

The legal system is an important element in the Constitution of Papua New Guinea, partly because it provides the means by which the Constitution is enforced, and partly because it can be seen as evidence of the almost obsessive legalism which pervades the Constitution. It is interesting also in that it seeks to establish a body of rules, administered in the judicial courts, in which an important element is the traditional custom of the people, rather than the imposed common law of England.

The Supreme Law of the Country is the Constitution ${ }^{49}$; in accordance with its provisions, Parliament may make Organic Laws, which have the force of Constitutional laws and may be repealed or amended only in accordance with the special procedures laid down by the Constitution ${ }^{50}$. Many parts of the Constitutional laws can be amended only by a "prescribed majority" which may be as much as a three-fourths majority of all members of the Parliament. All constitutional amendments require at least an absolute majority of members ${ }^{51}$. In all cases special procedures, especially with regard to notice, must be followed. Below the Constitutional Laws of the country, in the hierarchy of legal norms, come the Acts of the Parliament, and then various types of subordinate legislation. Then, in cases where no written law applies, the law is the "underlying law"52. Upon Independence, not only were all Australian and Imperial laws applying in the country repealed by the Papua New Guinea Independence Act 1975 (Australia), but the Laws Repeal Act 1975 (Papua New Guinea) repealed, as of the last moment of the day preceding Independence day, all enactments made under authority of the colonial laws. However, Schedule 2 of the Constitution which as part of the Constitution, came into effect at the commencement of Independence Day, re-enacted the pre-Independence laws, but under the authority of the people, rather than of Australian law.

\footnotetext{
47 C. f. For a n account of Judicial Review of Constitutional Law, see G. J. Lindell, "Duty to Exercise Judicial Review" in L. R. Zines, ed., Commentaries on the Australian Constitution (Sydney 1977): for Judicial Review of Administrative Action in other common law systems see S. A. de Smith, Judicial Review of Administrative Action (London, 1973); H. Whitmore and M. Aronson, Review of Administrative Action (Sydney 1977).

48 Constitution, Part VI. 2. H.

49 Ibid., s. 11.

50 Ibid., s. 12-17.

51 Ibid., s. 17

52 Ibid., ss. 9,10 .
} 
As Barnett ${ }^{53}$ and Wolfers ${ }^{54}$ have pointed out, statutes and regulation formed virtually the whole of 'the law' with which the traditional Papua New Guinean came into contact. It was only with the arrival of roads and motor transport (law of torts) and the cash economy (law of contracts) that the need for interstitial substantive law arose, though the Courts had always imposed the requirements of the common law of evidence and procedure even in matters affecting only indigenous Papua New Guineans. The need for a system of laws to which reference could be made in the interests of certainty, in order to reach decisions based upon pre-established principles, was thought by the CPC to necessitate constitutional provision for an interstitial law, especially with the growth of an increasingly urbanised society ${ }^{55}$. Again, this was a conscious choice, for the members of the CPC were well aware of systems of "People's Justice" operating in China and in parts of Africa; the establishment of such systems had been advocated in Papua New Guinea ${ }^{56}$, and to a significant extent, there was provision under the Village Courts Act 1973 for a system of popular tribunals to decide a limited range of cases in Papua New Guinea. The provisions of the Constitution, especially ss. 20, 21 and Schedule 2, give a n example of the dualism which results from the attempt to combine a dedication to establishing Papua New Gưinean ways with a strong attachment to legalism. The disillusionment of Papua New Guineans with aspects of the legal system was a result of the failure of imposed law adequately to deal with conduct which was, in most traditional Papua New Guinean societies, culpable - e.g. sorcery, adultery, and incest (as measured by traditional standards). It also punished action which was justified, or even required, by traditional standards, such as trespass to land, and retaliatory wounding or killing. The official courts did, after 1963, take some traditional values into account, not in deciding whether or not a criminal offence had been committed, but in determining sentence ${ }^{57}$. This was assisted to some extent by the Native Customs (Recognition) Act 1963, and legislation relating to land specifically required reference to custom. Despite efforts to extend the official courts so that they would provide a complete system of dispute resolution ${ }^{58}$, unofficial dispute settlement procedures continued to operate, of ten openly. These procedures were of ten preferred by the people ${ }^{59}$. This led to a popular demand for traditional tribunals at village level applying customary rules ${ }^{60}$ but no action was taken until after the 1972 elections. The Village Courts Act 1973 was established after an official inquiry, and village courts, whose magistrates are elected by the people and apply 'traditional rules' - in fact, which settle disputes ac-

53 T. E. Barnett, "The Courts and the People of Papua New Guinea" (1967) 1 Journal of the Papuaand New Guinea Society 95 ; op. cit. n. 12; "Law and the Legal System" in P. Ryan, ed., Encyclopaedia of Papua and New Guinea (Melbourne/Port Moresby 1972); "Law and Justice Melanesian Style" in A. I. Clunies Ross and J. Langmore, eds., Alternative Strategies for Papua New Guinea(Melbourne 1973).

54 Op. cit. n. 4.

55 The C. P. C. did notdeal with the laws specifically, but incorporated a reference when dealing withthe question of "Papua New Guinean Ways" (C. P. C. Report, paras 2.97-120).

56 A. Paliwala, J. Zorn and P. J. Bayne, "Economic Development and the Changing Legal Systems of Papua New Guinea" (paper delivered at the 1973 Conference of the Australian Universities Law Schools Association, Port Moresby).

57 R. A. Smithers, "The Rule of Law and the Administration of Justice in an Emerging Society" in International Commission of Jurists (Australian Section) The Rule of Law in an Emerging Society; Port Moresby, 1970, Johnson, op. cit., n. 8; J. F. Hookey, "The Clapham Omnibus in Papua and New Guinea" in Brown, op. cit., n. 3; Barnett, (1973), op. cit. n. 53.

58 Barnett, op. cit., n. 12; P. J. Quinlivan, "Local Courts in Papua New Guinea; Bringing Justice to the People" in Bayne and Zorn, op. cit. n. 21.

59 Fenbury, op. cit., n. 12; P. G. Sack, "Self-help, Group Solidarity and Law Enforcement" (1972) 42 Oceania 249; P. G. Sack, "Dukduk and Law Enforcement" (1972) 43 Oceania 96; A. M. Strathern, op. cit. n. 12; P. Urami, "The Warkurai Ni Gunan" (paperdelivered at the Seventh Waigani Seminar, Port Moresby 1973); J. L. Goldring, "Administration of Justice in a Society Between Two Cultures" in I. Pilowski, ed., Cultures in Collision (Adelaide 1975).

60 D. P. Derham, Report on the Systems for the Administration of Justice in the Territory of Papua New Guinea (Canberra 1963); D. P. Derham "Law and Customs in the Australian Territory of Papua and New Guinea" (1963) 30 Univ. of Chicago Law Review 495; Fenbury, op. cit., n. 12; D. M. Fenbury, Practice Without Policy (Canberra, 1978), Ch. 6; N. D. Oram "Administration, Development and Public Order" in Clunies Ross and Langmore, op. cit. n. 53; N. D. Oram "Law and Order" (1973) New Guinea, Australia and the Pacific (4) 4.; N. D. Oram "Village Courts: the Arguments Answered" in Bayne and Zorn, op. cit. n. 21; N. D. Oram "Grass Roots Justice; Village Courts in Papua New Guinea" (unpublished, 1976). 
cording to popular concepts of justice - were established. The Constitution envisages that these tribunals will coexist with the official courts; village courts will settle matters which are regarded as petty civil claims, but have no jurisdiction to deal with serious crimes, which should be referred to the police and judicial courts. In practice, even some serious crimes are settled by mediation.

This type of arrangement appears quite acceptable. However, the Constitution, in Schedule 2, establishes traditional custom as a basis of underlying law; the rules according to which the courts settle disputes or decide contentious questions, in the absence of statutory provisions, are to be drawn from "custom", as well as the rules of the common law. The Courts and the Law Reform Commission are required to develop the underlying law. The intention appears to be that the common law is to be discarded where it is less appropriate than a principle derived from custom. The intention has, apparently, not been put into operation to date by the Courts $^{\mathbf{6 1}}$, but the Law Reform Commission has published a Working Paper ${ }^{62}$. This division ignores that "customs" are of ten not rules in the sense that laws are rules; principles which can be derived from an observation of customary dispute-settlement or the imposition of traditional or popular sanctions cannot be separated from the procedures in which they operate $^{63}$. A principle which purports to be derived from custom will of ten have an application in only one or two of several hundred societies, and to impose it on other societies may be just as inappropriate as the imposition of a rule of English law ${ }^{64}$. What is more, to institutionalise a principle derived from custom is to give it the status of a legal rule, subject to the same sort of institutionalised ossification, and the same vicissitudes of judicial interpretation as the principles of English law. The "traditional" or popular culture from which the rule is taken is likely to change, and the values of the people which the principle reflects very likely will change; thus the principle will have to be changed by legislation ${ }^{65}$. It may be that the constitution of Papua New Guinea makes a category-mistake when it elevates custom into a source of law. However, it should be remembered that there is popular feeling against the imposition of English law, and that the principles derived from custom may provide more appropriate sources of law than does the English common law. Nevertheless, there will be the phenomenon of two parallel dispute settling mechanisms operating in the country, each applying "custom", but, one suspects, applying totally different principles in totally different procedural settings.

The village courts will only operate between villagers at a personal level. The criminal law, and the legal procedures which control government action are primarily the province of the judicial courts. Therefore there is a problem of access to legal rights. Papua New Guinea has for many years enjoyed a relatively effective system of legal aid in major criminal and some civil cases ${ }^{66}$. This legal aid is provided at public expense by the Public Solicitor, whose office and independence are confirmed and guaranteed by the Constitution. Thus there is some assurance that the legal rights guaranteed by the Constitution - especially the "basic human rights" guaranteed by Division III. 3 of the Constitution - will, in fact, be enforced.

61 N. K. F. O’Neill, “The Judges and the Constitution - The First Year” (1976) 4 Melanesian Law Journal 242.

62 Papua New Guinea, Land Reform Commission, Working Paper No. 4, Declaration and Development of Underlying Law (Port Moresby 1976) commented upon by D. Weisbrot at (1977) 5 Melanesian Law Journal 152.

63 A. L. Epstein "Procedure in the Study of Customary Law" (1970) 1 Melanesian Law Journal 51; Barnett (1973) op. cit. n. 53: P. G. Sack, "The Cult of the Eight-Foot-Yam: Primitive Provocations on Law and Development" (Paper delivered to World Congress of Legal Philosophy, Sydney/Canberra 1977).

64 B. J. Brown"'Outlook for Law in New Guinea" (1971) Oceania 244; J. L. Goldring, “Just Law for Primitive Society” (1971) 6 Sydney Law Review 371.

65 M. P. Jain "Custom as a Source of Law in India" (1963) 3 Jaipur Law Review 96.

66 T. P. W. Deklin and P. D. Donigi, "Legal Aid in New Guinea" (1972) 3 Singapore Law Review 172. 


\section{Legalism and Nationalism}

Though the Constitution speaks as if it is the voice of a people committed to the maintenance of strong traditional cultures, its very form is a denial of those cultures. The mere existence of a written constitution is an admission that at least one value has been imported from Western Europe. The expression "the rule of law" is used in the Constitution itself67. The whole Constitution presupposes that there are ideals higher than those of the political ends of any individual or group which strives for power at any given time. To some extent, the Constitution, though it is the formal source of all legal authority, is not the only source of law; s. 158 (2) provides that "In interpreting the law the courts shall give paramount consideration to the dispensation of justice." and s. 155 (4) states that "Both the Supreme Court and the National Court have an inherent power to make, in such circumstances as seem to them proper, orders in the nature of prerogative writs and such other orders as are necessary to do justice in the circumstances of a particular case." These references to "justice" as if it were an immanent body of principle to which reference may be made in order to determine certain issues suggests that there is some "natural law" whose existence and content is obvious to all. Yet these provisions of the Constitution seem to fit ill with the specific provisions especially in Schedule 2, which provide for the declaration and development of an "underlying law", or an interstitial law which provides a solution in those cases where the legislature has not made any provision by statute. The rest of the Constitution establishes a legislative and judicial structure whose primary function is to provide principles in accordance with which the affairs of men may be governed with certainty, and in accordance with the wishes of the majority speaking through their representatives.

Traditional Papua New Guinea societies did not have such a structure. There certainly were established customs: but these customs were essentially flexible, both in substance and in procedure. Their function was to ensure that the community continued to exist as a community, and to maintain a social balance ${ }^{68}$. It may well be that if such societies had not been brought into contact with the rest of the world they might have developed, or been forced to adopt some system whereby the members of the community would have been able to plan their activities with some certainty, but it is less clear, and probably less likely, that the structure of the governmental and dispute-settling systems would have taken a form like that imposed by the constitution of Papua New Guinea.

The Constitution of Papua New Guinea is, in many respects, the western left-liberal's dream: a strong and entrenched Bill of Rights, including guarantees of freedom of movement, of conscience, of expression and of the protection of the law; a representative and responsible parliamentary democracy, with organisations and individuals protected so far as possible from outside influence; a free and independent judiciary administering laws conforming as far as possible with the attitudes and aspirations of the people; strict controls on the spending of public money, protection of the people from administrative abuse, and safeguards even in times of declared national emergency. If liberal elements in the United Kingdom, Canada or Australia were asked to write a constitution, this, mutatis mutandis, might be the constitution they would write.

67 Constitution, s. 57 (2) (b).

68 H. I. P. Hogbin, Law and Order in Polynesia (London 1934); L. Pospisil, Kapauku Papuans and Their Law (New Haven 1973); A. J. Strathern, "A Matter of Prestige and Power" (1973) 1 Melanesian Law Journal (3) 23; A. M. Strathern "Legality or Legitimacy" (1972) 1 Melanesian Law Journal (2) 5; A. M. Strathern, op. cit. n. 12; T. Barnett, op. cit. nn. 12, 53; P. Sack, op. cit. n. 59; P. G. Sack, Land Between Two Laws (Canberra 1973); Lawrence, op. cit. n. 3. 
It is, however, a constitution which depends almost entirely in its operation on legalism; enforcement by the Courts (as provided in ss. 22, 23, 57 and 58 of the Constitution); interpretation of the Constitution by the Supreme Court (ss. 18 and 19); limits on administrative power to be measured against standards laid down in statute or in common law principles such as "natural justice" (ss. 59, 155), and enforced either by the Courts or the Ombudsman Commission, which appears to be designed as a quasi-curial body acting in parallel with the judicial courts. The institutions, the commissions, and the tribunals which are established by the Constitution for a variety of purposes, such as the Ombudsman Commission; the tribunals established to consider charges of breaches of the Leadership Code; the Public Services Commission; the Judicial and Magisterial Services Commission and the tribunals established to hear charges of misconduct against judicial officers, as well as the courts and legal officers which make up the National Judicial System, all exemplify a faith in legalistic procedures. Though the functions which these bodies have may have little to do with the administration of laws, the Constitution envisages, that, except in cases of declared national emergency, when the executive may make regulations and orders, policies will be enacted in the form of statutory laws. These laws define the limits of activities; transgressions of those limits will be determined by courts and court-like bodies, according to procedures and rules derived from the procedures of the common law courts, and visited with sanctions by the courts and tribunals after hearings and determinations which are essentially court-like. The government of the Independent State of Papua New Guinea is designed as a government of laws rather than a government of men. The laws which govern and the fact that they govern spring equally from a tradition of which the imposed colonial laws were merely a part.

\section{National Resources and Legalism}

At present, the people of Papua New Guinea seem enthralled with their Independent status, and a re filled with national pride. For them the Constitution has real meaning. They, or people they know personally, were probably involved in the consultative process which preceded the final formulation of the Constitution. It may be that the rights and values which are embodied in the Constitution will become as much of the personal consciousness of each individual Papua New Guinean as Constitutional rights are of the consciousness of every American, regardless of his colour, class or creed. This will depend on the education system of the country.

The problem remains that Papua New Guinea is a developing country. Apart from some tropical agricultural produce (copra, coffee, timber, cocoa and rubber), fisheries and copper, it has few exports. It has little industry, and no sources of petroleum. Its communication system depends on microwave links and aircraft. Most of its people are still illiterate, though mass education is a significant policy. There are however, very few people with the training, and especially, the experience, necessary to operate modern technology of government and law. What administrators and institutions do is governed by law. Lawyers are needed to translate policy objectives into forms that can be enacted as statutes by the legislative machinery and enforced by the courts. The bounds of administrative competence are expressed by means of laws. The observance of legal norms, whose making and interpretation is itself determined in accordance with legal principles expressed as laws, is enforced by legal procedures, which are guaranteed by the supreme law, the Constitution. Sanctions are prescribed by laws and imposed by courts. 
The average man in the streets or villages of Papua New Guinea is not equipped with the skills necessary to interpret and apply these laws. Law in Papua New Guinea is as, if not more, mysterious a process as it is in any other country. The system of law which has been adopted is such that it cannot work without a large supply of trained personnel. It says much for Papua New Guinea that since 1963, the typical magistrate's court has changed from being a mere appendage of the European patrol officer's function, to being a permanent institution staffed by well-trained Papua New Guinean officials. Papua New Guinean legal practitioners have taken over many of the functions previously performed by white lawyers. However, there is not at present, and is unlikely to be within the next few years, a significant proportion of Papua New Guineans among the members of the National Court, who have the vital responsibility of interpreting the Constitution and the written laws, and in shaping the interstitial laws. Nor is the majority of advocates who will present arguments to the higher courts yet Papua New Guinean. One must ask whether Papua New Guinea can afford to devote scarce resources to the employment of foreign lawyers until there are sufficient national lawyers to meet the requirements which the legalistic system demands.

The priorities of the country must determine the allocation of scarce resources, and allocation of scarce resources is always a political question. The constitution provides itself that between three and five years after Independence, the Constitution must be reviewed by a Commission similar in composition to the CPC. The final say on revision of the Constitution rests, however, with the Parliament, and this, like all "Westminster" type Parliaments, is for most purposes subject to the control of the Government. The Government then, will influence any changes that will be made. There are many areas in which administrative convenience would be suited by changes in the Constitution which might not accord with the general philosophy of the National Goals and Directive Principles. Whether the guaranteed rights of the individual, the system of controls of the abuse of executive power, and the procedural safeguards which ensure at least some measure of participation by the people in the processes of government and administration thus depend to a large extent on the attitude of the Government, and this will be influenced by the political pressures on the Government relating to the allocation of resources.

\section{Legalism and the Political Future}

The National Goals and Directive Principles are an important part of the Constitution of Papua New Guinea, as well as distinguishing it from other Constitutions. They embody a set of political and economic values, which were accepted by the Constituent Assembly as the values for which the political processes of the country should aim. Those values, development in the sense of integral development of the individual with society, national self-reliance, and emphasis on Papua New Guinea ways. The values are those of a model of development which Paliwala, Zorn and Bayne, in an influential paper which has been available in Papua New Guinea in various forms since 1973, call "redistribution with growth"; this is a model which requires the economy of Papua New Guinea not to become integrated with the multi-national capitalist economy in the full sense, but to exercise controls over the way in which funds available to the country and the people are spent. It requires recognition of popular forms of social and economic organisation.

The Constitution, though it embodies statements of National Goals, may be seen, in one sense at least, as a negation of the values of the National Goals. The system of a constitution interpreted and enforced by the judicial courts is one which grew up in the economic and so- 
cial conditions of western Europe in the eighteenth century. It is not a Papua New Guinean institution in any sense; the values, no matter how laudable, are not Papua New Guinean, but values of western European liberals. Constitutionalism has been closely associated with bourgeois liberal economics. The connection is not a necessary one, but the institutions which the Constitution of Papua New Guinea erects are institutions taken from societies which, the National Goals would seem to indicate, the people of Papua New Guinea have no wish to emulate. This does not mean that the types of rights protected by the Constitution, the controls on corruption, and on foreign influence in the political process are not highly desirable in the circumstances. Given that they are, there was probably no alternative to the adoption of a Constitution with legal controls in order to achieve the desired ends. There was the added factor that, in Papua New Guinea, the "Westminster" system of responsible and representative government was familiar, and was known to allow a fair measure of popular participation in the processes of government. The rights and values which, in many cases, are part of the Constitution were rights and values protected by pre-Independence legislation (e. g. the Human Rights Act 1971). Though there was some resentment at the laws which had been imposed by the colonial power, the superior courts at least had established for themselves a reputation of reasonable impartiality, the the extent that the CPC was able to recommend that the Courts be entrusted with the interpretation and enforcement of the Constitution, even at a time when the Australian High Court, the model most immediately familiar to Papua New Guineans, was increasingly under criticism as playing an unduly political role. It may be that, to use Andrew Strathern's words, the Supreme Court commanded such 'prestige and power' 69 that the people felt confident in it as an institution with an important and potentially dangerous political role.

To decide that the Constitution, the statement of basic political structures and, either expressly or impliedly, of political values, is to be enforced through the judicial courts is to decide on an system saturated with legalism. In the circumstances of modern state emerging from colonial status, such a decision is almost inevitable. If, having made that choice, the framers of the Constitution decide that the circumstances of the country and the political ends they wish to serve are such that controls on various types of conduct are necessary, then legal controls are the obvious ones. However, the legal system, even if it is to be a legal system in which the local traditions have a specified, if residual role, may be a two-edged weapon. It may serve the ends to which the framers of the Constitution intend, but it may also operate, because of the nature of law and lawyers, in a way which may inhibit the development of the country and the people in the way that they wish to develop. Any written Constitution involves a degree of legalism. That of Papua New Guinea, while making some very different attempts to provide a direction and structure for a particular type of development, is legalistic to an unusually high degree. The legalism is itself a consequence of the contact with colonial institutions, and the political future of the country may thus be unduly influenced by the heritage of the imposed law. 


\title{
Legalism Rampant: The Heritage of Imposed Law and the Constitution of Papua New Guinea.
}

\author{
By JOHN GOLDRING
}

The Constitution of Papua New Guinea, which came into force when Papua New Guinea became Independent, is autochthonous. It seeks to give, of its own force, legal effect to all the statute and judge-made law of the country, so that the authority of law is in no way dependent on any colonial law in force prior to Independence. It also seeks to establish the customs of the people, which were scarcaly recognised by the legal system prior to Independence, the status of ,underlying law' and to require the legislature and the courts to give effect to the traditions of the people. The Constitution itself calls for great significance to be attached to ,Papua New Guinean Ways”. The Constitution is the result of a process of popular consultation unparallelled in any other country.

Despite this, the Constitution of Papua New Guinea is firmly rooted in the traditions of Western culture, specifically, the Westminster system of government and the English Common Law. It is a complicated and highly legalistic document, which depends for its enforcement on judicial review and enforcement by a court and lawyers trained in the Common Law and brought up to respect the traditions of responsible and representative government. Despite the exhortations in the Constitution to respect and enforce the traditions of the country, it is itself an instrument which requires for its effectiveness a legal culture which is not indigenous to Papua New Guinea, but is, in fact, the heritage of the Common Law which was imposed upon the country by its colonial rulers.

\section{Labour Legislation in Algeria}

\section{By GUNTER WIEDENSOHLER}

The Algerian Law No. 78-12 of 5th August, 1978 (Statut général des travailleurs) is a significant example for the concept of labour law in a socialist country in development. A remarquably high importance is given to labour relations even in the Charter and the Constitution. Further it is surprising to see that freedom to strike does not exist in the public economic sector nor the principle of state sovereignty of collective bargaining, social security regulations. At various places there are hints to the social obligation to work, the principle of achievement motivated remuneration and to the significance of the vocational school system. The new law is expected to lead to a higher standard of discipline and responsibility within the labour relations.

\section{The Myth of the Hung-Kings and the National Self-Evidence of the Vietnamese}

The fact that marxism is the ruling ideology in Vietnam of ten seems to have the appearence to have overcome nationalism, which, otherwise, represents the most effective political ideology in the Third World. It is the task of this essay to prove by means of an analysis of the official interpretation on the myth of the Hung-kings that this fact is deceptive. These Hungkings were the legendary founders of the Vietnam state about whom there has been much report in the vietnamese annales. In the quest for nationalidentity the historians of the Socialist 